\title{
EFFICIENCY OF SECOND INSTAR LARVAE OF CHRYSOPERLA CARNEA TO SUPPRESS SOME PIERCING SUCKING INSECTS INFESTING CANTALOUPE UNDER SEMI- FIELD CONDITIONS
}

\author{
YOUNES, M.W. F. ${ }^{1}$, I. F. SHOUKRY ${ }^{2}$, SAMIA A.G. METWALLY ${ }^{3}$ and \\ YOMNA N. M. ABD-ALLAH ${ }^{3}$ \\ 1 Zoology Department, Faculty of Science, Menoufia University,Egypt. \\ 2 Zool. Dept. Fac. Of Sci. Zagazig Univ., Egypt. \\ 3 Plant protection Research Institute, ARC, Dokki, Giza, Egypt.
}

(Manuscript received 10 April 2012)

\begin{abstract}
Evaluation the efficiency of Chrysoperla carnea second instar larvae, of predator were released at three different rates (3, 5 and 7 larvae / plant) for suppression aphids the cotton - melon aphid, Aphis gossypii Glover and the green peach aphid, Myzus persicae Sulzer as well as nymphs and pupae of Bemisia tabaci Genn. on cantaloupe ( Cucumis melo L.) plants (the local cantaloupe variety, Arafa) .The experiment was conducted under semi-field conditions during early summer plantation season of 2010 . The promising and best results were obtained after 21 days from releasing date at rate of 5 predatory larvae / plant, however, these larvae reduced populations of aphids and whitefly by 73.9 and $83.07 \%$, respectively.
\end{abstract}

\section{INTRODUCTION}

The chemical controlling methods by insecticides are currently used inspite of their power contamination, volatilization and bioaccumulation. It could interchange in the air - water- soil system at rate that depends on various climatic and environmental factors putting the whole food chain at risk (Vighi et al., 1997). Also the chemical insecticides induced insect resistance, phytotoxicity, unbalance in the normal biotic ecosystem by overcoming upon the natural insect enemies and environmental pollution resulting from the undesirable chemical residues. Therefore, it is necessary to apply alternative methods to control the insect pests, and one of these is biological control by predacious insects such as Chrysoperla carnea (Stephens) which used in the present study as biological control agents on some cantaloupe pests such as Aphis gossypii Glover, Myzus persicae Sulzer and Bemisia tabaci Genn.. The common green lacewing, Ch. carnea appears to be a good candidate for use in I.P.M. programs information (Aziza et al., 2007). A control option for these insect pests reviewed here includes using $2^{\text {nd }}$ instar larvae of $C h$. carnea.

The predator is usually found on different parts of plants together with aphids and whiteflies and this species feeds on adults and immature stages of its preys. 


\section{MATERIALS AND METHODS}

The aim of this experiment is to studying the efficiency of $2^{\text {nd }}$ instar larvae of Ch. Carnea (Stephens) as biocontrol agent against some sap-sucking pests, ( $A$. gossypii and M. persicae) as well as nymphs and pupae of B. tabaci on cantaloupe plants under semi-field conditions. A greenhouse of about $270 \mathrm{~m}^{2}$ was chosen in the Experimental Farm of Central Laboratory for Climate and Meteorology. The chosen area was divided into 12 plots ( 9 plots as treated groups and 3 plots as control group).Each plot (replicate) measures $22.5 \mathrm{~m}^{2}$, and all plots distributed in a complete randomized block design. Sowing seeds of the local cantaloupe variety (Arfa) was applied on $16^{\text {th }}$ February 2010 at a distance of $50 \mathrm{~cm}$ between hills.

The normal agricultural practices for cultivation were performed and no specific chemical treatments were conducted during the whole period of study. Envelopes (A4 size) containing the second larval instar of Ch.carnea were obtained from Mass Rearing Unit of the Faculty of Agriculture, Cairo University, which were used for transportation of larvae. A serious of white paper sheets displaying eggs of Ephestia kuehniella (Zell.) were found in each envelope, so the larvae could feed freely until they were dispatched on the plants. Releasing $2^{\text {nd }}$ instar larvae of $C h$. carnea was carried out on April $29^{\text {th }}$ at three ratios, 3, 5 and 7 larvae per plant. Larvae were brushed on the treated plants by using a fine and smooth paint brush. Samples of 120 leaves (30 leaves / treatment and the same for control group) were randomly picked out after $1,3,5,7,11,14$ and 21 days from releasing. Leaves were kept in polyethylene bags to be transferred to the laboratory in order to be examined by a binocular stereomicroscope. Counts of $B$. tabaci immature stages and aphids were determined by inspection the whole leaf area.

Duncans multiple range test (1955) was used to clear the significanct among the reduction percentages after each release as well as in case of the overall mean reduction in aphids and Bemisia tabaci population.

The reduction percentages in whitefly immature stages population and aphids mean numbers were calculated according to Abbott's formula (1925)

$\frac{\text { Control - treatment }}{\text { Control }} \quad \mathrm{X} 100$




\section{RESULTS AND DISCUSSION}

\section{1- Effect of Ch. carnea predator as biological control agent on population of}

\section{A. gossypii and M. persicae:}

Data presented in Table (1) indicating the efficiency of $2^{\text {nd }}$ instar larvae as biological agent for controlling aphids population on cantaloupe plants when introduced in the greenhouse at three different ratios, 3, 5 and 7 larvae/ plant. Twenty four hours after releasing, the efficiency of $2^{\text {nd }}$ instar larvae of Ch. carnea was determined in all treatments under investigation. Aphid populations being 7.13, 3.7 and 6.03 aphid individuals / leaf at the $1^{\text {st }}$ day post-treatment with 3,5 and 7 predaceous larvae/ plant, respectively. However, aphid's population increased in the control treatment to reach 21 individuals/ leaf. The corrected reductions in aphid counts were calculated according to Abbott's formula as 66. 51, 82.6 and 71.7 than those of the control in plots received 3, 5 and 7 larvae/ plant, respectively. Three days after predator release, results demonstrated that the mean number of aphids reached 4.3, 7.1 and 5.4 individuals/ leaf in plots treated with Ch. carnea at rates of 3, 5 and 7 predaceous larvae/ plant, respectively, compared to 17.6 individuals/ leaf in the control group. Thus, the corrected reduction percentages, opposed to the control mean counts, were $75.6,65.6$ and $69.5 \%$, respectively.

Two days later ( 5 days after release), the predaceous larvae gave reduction percentages as $85.05,74.04$ and $49.9 \%$, while the mean counts of aphids infested cantaloupe plants in plots treated with 3, 5 and 7 predaceous larvae/ plant were 2.5, 4.3 and 8.3 individuals/ leaf, respectively, compared to 16.5 individuals / leaf infesting control group.

One week after release the predator, the mean counts of aphids became $1.17,2.5$ and 11.2 individuals / leaf of at rates of 3,5 and 7 predacious larvae/ plant, respectively, opposed to 15.4 individuals / leaf as mean count/ cantaloupe leaves of control group. However, the corrected reduction percentages according to Abbott's formula were $92.42,83.8$ and $27.48 \%$ in plots received 3,5 and 7 predaceous larvae

/ plant, respectively.

Eleven days after release, the mean number of aphids reached 1.8, 1.74 and 3.44 individuals/ leaf, in plots treated by the above mentioned three rates , 3, 5 and 7 larvae/ plant, respectively. However the control plants harboured 12.98 individuals/ leaf. The calculated reduction gave percentages of $86.5,86.61$ and $73.5 \%$, respectively. 
Two weeks after release, aphid populations increased in the control group to reach 31.6 individuals/ leaf in contrast to $6.7,6.2$ and 3.48 individuals / leaf, on cantaloupe plants treated with 3, 5 and 7 predaceous larvae / plant, respectively. The corrected reduction percentages for aphids mean counts compared to control groups were $78.88,80.41$ and $88.96 \%$ in plots treated with the above mentioned rates, respectively.

Results obtained after three weeks of release clearly indicated the presence of aphid individuals on cantaloupe plants, but in a few numbers, where aphids mean counts were 3.65, 2.5, 0.9 and 4.4 individuals/ leaf for the forecited three treatments and control, respectively. Thus giving 26.5, 43.93 and $80.32 \%$ reductions in aphids population since releasing of $2^{\text {nd }}$ instar larvae of Ch. carnea at 3, 5 and 7 larvae/ plant, respectively Table (1).

Generally, data presented in Table (1) demonstrated that releasing of $2^{\text {nd }}$ instar larvae of Ch. carnea at the three different rates (3, 5 and 7 larvae/ plant) induced to general reduction in aphid populations than the control treatment. The statistical analysis revealed that, the efficiency of $2^{\text {nd }}$ instar larvae of Ch. carnea was more evident when released at 5 larvae/ plant as biocontrol agent against aphids attacking cantaloupe plants under greenhouse conditions. Accodingly, it gave the highest overall mean percentage of reduction in aphid populations (73.9\%), followed by 3 larvae/ plant $(73.07 \%)$. On the contrary releasing of $2^{\text {nd }}$ instar larvae of $C h$. carnea at rate of 7 larvae/ plant gave an overall mean of $65.91 \%$ reduction in aphid populations which considered the lowest reduction percentage.

From the above mentioned results, it is clear that releasing at 5 larvae / plant may be appropriate application rate to reach satisfied reduction of aphids on cantaloupe plant.

The present results are in harmony with those of Gurbanov (1982), in USSR, who found that after one week of releasing Chrysopa carnea (3- 4 days old eggs and $1^{\text {st }}$ and $2^{\text {nd }}$ instar larvae) against $A$. gossypii at the predator-prey ratio, $1: 1$, the reduction percentage was $98.5 \%$. Driesche et al. (1987), in USA, found that the three aphid species (M. persicae, A. gossypii and Macrosiphum euphorbiae) which considered as main pests of greenhouse crops could be highly controlled by releasing Ch. carnea. Shuvakhina and Novozhilov (1987), found that highly reduction in the aphid populations in cucumber in glasshouses in USSR related by using the Far Easter lacewing, Chysoperla sinica.

Successful use of Chrysopa perla for control of A. gossypii on cucumber in USSR, and found that this predator used as biological control agent against $M$. persicae and against Aulacorthums circamflexum on decorative plants (Ushchekov, 
1989). El-Arnaouty and Ferran (1993), in Egypt, stated that M. persicae was caught as first prey by larvae of $C$. carnea when it reared on $M$. persicae as well as eggs of Ephestia kuehniella (Zell.)

Burgio et al., (1997), studied the effect of biological and integrated control of A. gossypii infesting cucumber (cv Darina) and melon (cv. Harper) during April - May in plastic tunnels in Italy. They stated that wild predators (Coccinellids and Ch. carnea) were essential for complete aphid control in both of vegetable crops. In Egypt, El-Arnaouty et al. (2000), obtained best results in the control of M. persicae by releasing $2^{\text {nd }}$ instar larvae of $C h$. carnea on green pepper plants under greenhouse conditions than those obtained after releaisng eggs and combination between eggs and $2^{\text {nd }}$ instar larvae. Biological control of aphids with Ch. carnea on strawberry was conducted by Turquet et al. (2009).

Table 1. Efficiency of $2^{\text {nd }}$ instar larvae of $C$. carnea in reducing aphid* populations on cantaloupe plants under semi - field conditions (greenhouse) at indicated days after releasing.

\begin{tabular}{|c|c|c|c|c|c|c|c|c|c|c|c|}
\hline \multirow{2}{*}{\multicolumn{2}{|c|}{ Treatments }} & (1) & rive & ger & & & & & & & \\
\hline & & $1^{\text {st }}$ & $3^{\text {th }}$ & $5^{\text {th }}$ & $7^{\text {th }}$ & $11^{\text {th }}$ & $14^{\text {th }}$ & $21^{\text {st }}$ & $\begin{array}{c}\text { Mean of } \\
\text { reduction } \\
(\%)\end{array}$ & $\begin{array}{c}\mathrm{F} \\
\text { value }\end{array}$ & $\begin{array}{c}\text { L. S. } \\
\text { D. }\end{array}$ \\
\hline \multirow{2}{*}{$\begin{array}{c}3 \text { larvae/ } \\
\text { plant }\end{array}$} & M & 7.13 & 4.3 & 2.5 & 1.17 & 1.8 & 6.7 & 3.65 & \multirow{2}{*}{$73.07^{\mathrm{a}}$} & \multirow{9}{*}{0.87} & \multirow{9}{*}{13.29} \\
\hline & $\mathrm{R} \%$ & $66.51^{\mathrm{a}}$ & $75.6^{\mathrm{a}}$ & $85.05^{a}$ & $92.42^{\mathrm{a}}$ & $86.5^{a}$ & $78.88^{\mathrm{a}}$ & $26.5^{\mathrm{b}}$ & & & \\
\hline \multirow{2}{*}{$\begin{array}{l}5 \text { larvae } \\
\text { /plant }\end{array}$} & $M$ & 3.7 & 7.1 & 4.3 & 2.5 & 1.74 & 6.2 & 2.5 & \multirow{2}{*}{$73.9^{\mathrm{a}}$} & & \\
\hline & $\mathrm{R} \%$ & $82.6^{a}$ & $65.6^{\mathrm{a}}$ & $74.04^{a}$ & $83.8^{\mathrm{b}}$ & $86.61^{a}$ & $80.41^{\mathrm{a}}$ & $43.93^{b}$ & & & \\
\hline \multirow{2}{*}{$\begin{array}{c}7 \\
\text { larvae/plant }\end{array}$} & M & 6.03 & 5.4 & 8.3 & 11.2 & 3.44 & 3.48 & 0.9 & \multirow{2}{*}{$65.91^{\mathrm{a}}$} & & \\
\hline & $\mathrm{R} \%$ & $71.7^{\mathrm{a}}$ & $69.5^{\mathrm{a}}$ & $49.9^{b}$ & $27.48^{c}$ & $73.5^{\mathrm{a}}$ & $88.96^{a}$ & $80.32^{a}$ & & & \\
\hline \multicolumn{2}{|c|}{ Control } & 21 & 17.6 & 16.5 & 15.4 & 12.98 & 31.6 & 4.4 & & & \\
\hline \multicolumn{2}{|c|}{$\mathrm{F}$ value } & 1.42 & 0.49 & 13.25 & 814.99 & 0.96 & 0.25 & 7.81 & & & \\
\hline \multicolumn{2}{|c|}{ L.S.D. } & 23.85 & 24.94 & 17.12 & 4.3 & 26.72 & 37.5 & 33.98 & & & \\
\hline
\end{tabular}

* Counting was recorded on two species (Aphis gossypii and Myzus persicae).

M : Mean numbers of aphids / cantaloupe leaf (data culculated from 3 replicates/ each releasing rate).

$\mathrm{R} \%$ : Reduction percentage of aphids' population / cantaloupe leaf.

- Means within a column followed by the same letter are not significantly different ( Duncans Multiple Range Test at 0.05) 
174 EFFICIENCY OF SECOND INSTAR LARVAE OF CHRYSOPERLA CARNEA TO SUPPRESS SOME PIERCING SUCKING INSECTS INFESTING CANTALOUPE UNDER SEMI- FIELD CONDITIONS

\section{2- Effect of Ch. carnea as predator on nymphs and pupae of B. tabaci:}

Data presented in Table (2) elucidate that there were reductions in numbers of immature stages of $B$. tabaci in all treatments than those infested cantaloupe leaves in the control groups during three weeks after release $2^{\text {nd }}$ instar larvae of $C h$. carnea under semi-field conditions.

One day after release, reduction in the immature stages of $B$. tabaci than the control group was observed. However, releasing of $2^{\text {nd }}$ instar larvae of $C h$. carnea at rates of 5 and 7 larvae / plant induced reduction in the mean count of immatures, where it was 3.23 and 3.28 individuals/ leaf, respectively as compared to 10.08 individuals/ leaf in control group. The mean reduction percentage of these rates in $B$. tabaci counts were 67.95 and $67.5 \%$, respectively. On the other hand, the mean number of $B$. tabaci immature stages in the same day after releasing the predaceous larvae at rate 3 larvae / plant was 25.54 individuals/ leaf more than the control group.

Threedays after release, the population of $B$. tabaci immatures increased in the control group to reach mean count of 24.4 individuals / leaf as compared to 2.54, 4.43 and 1.86 individuals / leaf in plots treated with 3, 5 and 7 larvae / plant, respectively. The corrected reduction percentage after 72 hours of release was 89.57 , 81.83 and $92.4 \%$ in plots treated with predaceous larvae at rates of 3, 5 and 7 larvae/ plant, respectively.

The mean reduction percentages in $B$. tabaci immature population stages after five days of releasing were $61.3,83.2$ and $69.55 \%$ in plots treated with 3,5 and 7 predaceous larvae / plant, respectively. It is quite clear from the obtained results that the mean count of immature stages in treated plots and control group was 7.91, $3.43,6.22$ and 20.43, respectively (Table, 2 ).

Observations were conducted at 7 and 11 days after releasing of $2^{\text {nd }}$ instar larvae of Ch. carnea confirmed descending in B. tabaci populations compared to the control group, where the mean counts after 7 days being 13.24, 2.4 and 10.6 individuals / leaf and 16.02, 2.64 and 9.45 individuals/ leaf at $11^{\text {th }}$ day in plot treated with rates of 3,5 and 7 predaceous larvae/ plant, respectively. However, the mean counts of

B. tabaci immatures that infested cantaloupe leaves in the control group plots being 16.5 and 21.42 individuals/ leaf after 7 and 11 days from release, respectively. The corrected reduction percentages were $52.5,85.5$ and $35.9 \%$ for $7^{\text {th }}$ day after releasing and $58.8,87.69$ and $55.9 \%$ for $11^{\text {th }}$ day after releasing.

As shown in Table (2), the population of $B$. tabaci immatures increased in the control groups to reach 31.3 and 66.1 individuals/ leaf, after two and three weeks, respectively. The mean numbers of $B$. tabaci immature stages in plots treated with $2^{\text {nd }}$ 
instar larvae of Ch. carnea at levels 3, 5 and 7 larvae/ plant being 7.63, 0.5 and 15.78 individuals/ leaf after two weeks and 10.1, 15.3 and 11.2 individuals/ leaf after three weeks. The mean reduction percentages among B. tabaci populations being 75.62 , 98.4 and $49.6 \%$ and $84.71,76.9$ and $83.06 \%$ after two and three weeks, respectively.

Generally, the statistical analysis clearly indicated that, releasing of $2^{\text {nd }}$ instar larvae of Ch. carnea at a rate of 5 larvae gave $83.07 \%$ which considered as the highest overall mean in reduction percentages among B. tabaci immaturs' population infesting cantaloupe plants under greenhouse conditions.

These results could be also proved from the weekly counts of $B$. tabaci after releasing of $2^{\text {nd }}$ larvae of $C h$. carnea at level of 5 larvae/ plant which led to significant reductions in $B$. tabaci population than the control groups during the period of the present study after releasing the biological control agent. This reduction percentage followed, significantly by 7 larvae / plant $(64.84 \%)$, on the other hand, the cantaloupe plants which treated with $2^{\text {nd }}$ instar larvae of Ch. carnea at rate of 3 larvae/ plant had the lowest reduction percentage in $B$. tabaci population (60.4\%).

The forecited results clearly indicated that releasing of $2^{\text {nd }}$ instar larvae of $C h$. carnea as biocontrol agent in applied control of $B$. tabaci nymphs and pupae infesting cantaloupe plants under greenhouse conditions at rate of 5 larvae / plant may be judicious application of this predator to control B. tabaci nymphs and pupae on cantaloupe plants.

In addition the above mentioned results revealed that releasing of $2^{\text {nd }}$ instar larvae of $C h$. carnea induced reduction in the percentage of

B. tabaci immatures at all employed rates of releasing predaceous larvae as well as at all time of examined observations with only one exception at $1^{\text {st }}$ day post - treatment with rate of 3 larvae/ plant where the mean count of B. tabaci was 25.54 individuals/ leaf.

These results are in accordance with findings of El-Sayed (1986), in Egypt, who reported that $C h$. carnea larvae fed on the body fluids of different immature stages, especially pupal stage of $B$. tabaci on eleven host plants. Abdel-Gawaad et al. (1990), in Egypt, recorded during field experiment that Chrysopa carnea larvae fed on the immature stage of $B$. tabaci preferably the pupae on 13 host plants.

In 1999, Zaki et al., studied the effect of two predators $C h$. carnea and $C$. undecimpunctata and two parasitods Diaeretiella rapae and Eretomocerus mundus against some insect pests including $A$. gossypii and $B$. tabaci. Authors found that releasing of these biological agents induced highly significant reduction of these pests at different rates of releasing. 
Comparison of development and predation of Ch. carnea on different densities of two hosts' B. tabaci and Amrasca devastans was studied by Sayed et al. (2000). They found that the larval durations of $C h$. carnea were significantly different among the number of larvae fed on $B$. tabaci and $A$. devastans.

The same application was carried out using Ch. carnea and other predators as bioagent to control A. gossypii, M. persica and B. tabaci in different areas of the world (Ermolaev, 2003).Hanafy (2004), studied in Egypt the efficiency of releasing $2^{\text {nd }}$ larval instar of Ch. carnea at different levels (3,6 and 9 larvae / plant) to control $A$. gossypii, M. pericae and B. tabaci which attacking cucumber (Medina variety) and came to conclusion agree with the obtained results in the present study which revealed that there was a positive relationship between the different levels and the reduction percentage of the treated pest.

Table 2. Efficiency of $2^{\text {nd }}$ instar larvae of $C$. carnea in reducing B. tabaci immature stages* on cantaloupe plants under semi- field conditions (greenhouse) at indicated days after releasing.

\begin{tabular}{|c|c|c|c|c|c|c|c|c|c|c|c|}
\hline \multicolumn{2}{|c|}{$\begin{array}{l}\text { Inspection } \\
\text { date }\end{array}$} & $1^{\text {st }}$ & $3^{\text {th }}$ & $5^{\text {th }}$ & $7^{\text {th }}$ & $11^{\text {th }}$ & $14^{\text {th }}$ & $21^{\text {st }}$ & $\begin{array}{c}\text { Mean of } \\
\text { reduction } \\
(\%)\end{array}$ & F value & L.S. D. \\
\hline 3 & $M$ & 25.54 & 2.54 & 7.91 & 13.24 & 16.02 & 7.63 & 10.1 & \multirow[b]{2}{*}{$60.4^{b}$} & \multirow{9}{*}{4.11} & \multirow{9}{*}{16.8} \\
\hline $\begin{array}{l}\text { larvae } \\
\text { /plant }\end{array}$ & $\mathrm{R} \%$ & - & $89.57^{\mathrm{a}}$ & $61.3^{\mathrm{a}}$ & $52.5^{\mathrm{a}}$ & $58.8^{\mathrm{a}}$ & $75.62^{\mathrm{ab}}$ & $84.71^{a}$ & & & \\
\hline 5 & M & 3.23 & 4.43 & 3.43 & 2.4 & 2.64 & 0.5 & 15.3 & & & \\
\hline $\begin{array}{l}\text { larvae } \\
\text { / plant }\end{array}$ & $\mathrm{R} \%$ & $67.95^{\mathrm{a}}$ & $81.83^{\mathrm{a}}$ & $83.2^{\mathrm{a}}$ & $85.5^{a}$ & $87.69^{a}$ & $98.4^{\mathrm{a}}$ & $76.9^{\mathrm{a}}$ & $83.07^{\mathrm{a}}$ & & \\
\hline \multirow{2}{*}{$\begin{array}{c}7 \\
\text { larvae } \\
\text { / plant }\end{array}$} & $M$ & 3.28 & 1.86 & 6.22 & 10.6 & 9.45 & 15.78 & 11.2 & \multirow[b]{2}{*}{$64.84^{\mathrm{b}}$} & & \\
\hline & $\mathrm{R} \%$ & $67.5^{\mathrm{a}}$ & $92.4^{\mathrm{a}}$ & $69.55^{\mathrm{a}}$ & $35.9^{\mathrm{a}}$ & $55.9^{\mathrm{a}}$ & $49.6^{\mathrm{b}}$ & $83.06^{a}$ & & & \\
\hline \multicolumn{2}{|c|}{ Control } & 10.08 & 24.4 & 20.43 & 16.5 & 21.42 & 31.3 & 66.1 & & & \\
\hline \multicolumn{2}{|c|}{$\mathrm{F}$ value } & 23.34 & 1.63 & 0.47 & 2.19 & 0.88 & 8.79 & 0.35 & & & \\
\hline \multicolumn{2}{|c|}{ L.S. D. } & 28.02 & 14.8 & 55.8 & 59.03 & 64.9 & 28.5 & 24.15 & & & \\
\hline
\end{tabular}

* Counting was recorded on nymphs and pupae.

M : Mean counts of B. tabaci immature stages / cantaloupe leaf (data from three replicates / each releasing rate).

$\mathrm{R} \%$ : Reduction percentage of $B$. tabaci immature stages / cantaloupe leaf.

- Means within a column followed by the same letter are not significantly different

( Duncans Multiple Range Test at 0.05) 


\section{REFERENCES}

1. Abbott, W.S. 1925. A method of computing the effectiveness of an insecticide. J. Econ. Ent. 18, 265 - 267.

2. Abdel-Gawaad, A. A., A. M. El-Sayed, F. F. Shalaby, and M. R. Abo El- Ghar. 1990. Natural enemies of Bemisia tabaci (Genn.) and their role in suppressing the population density of the pest. Agric. Res. Rev. 68 (1) : 185- 195.

3. Aziza, M. El-Gantiry, S. A. El-Arnaouty, H . M. Badawy and Nevien, M. Gaber. 2007. Biochemical variation in the life stages and populations of Chrysoperla carnea (Stephens) (Neuroptera : Chrysopidae) . Egypt J.Agric.Res., 85 (6) : 2121- 2138.

4. Burgio, G., R. Ferrari and G. Nicoli. 1997. Bioloical and integrated control of Aphis gossypii Glover (Homoptera :Aphididae) in protected cucumber and melon. Bollettino dell : Instituto di Entomologia . Guido Grandi della universita degli studi di Bologna.51 : 171-178.

5. Driesche, R. G. Van.,P. Vittum, and R. G. van .Driesche. 1987. Potential for increased use of biological control against greenhouse pests in Massachusetts.Res.Bull., Massachusetts Agric. Exp. Station (718) : 88 - 11, in opportunities for increased use of biological control in Massachusetts, 7pp.

6. Duncan, D. B. 1955. Multiple range and multiple F tests, Biometrics, 11, 1-42.

7. El-Arnaouty, S. A. and A. Ferran. 1993. Behavioural relations between the green lacewing, Chrysoperla carnea Steph. and its preys : I . Influence of previous feeding conditions .Egypt J. Biol . Pest Control 3 (1) : 111- 120.

8. El-Arnaouty, S. A., N. Gaber and M. F. S. Tawfik. 2000. Biological control of the green peach aphid Myzus persicae by Chrysoperla carnea (Neuroptera : Chrysopidae). Egypt. J. Biol. Pest Control. 10 (12) : 109 - 116.

9. El-Sayed, M. A. 1986. Further studies on the whitefly, B. tabaci (Genn.) and its natural enemies in Egypt. Ph. D. Thesis, Fac. Agric., Moshothor , Zagazig Univ., Egypt 232 PP.

10 . Ermolaev, N. E. 2003. Protection of Capsicum from pests using small-scale technology. Zashchita, Karantin Rastenii. 6 : 21- 22.

11. Gurbanov, G. G. 1982 . Effectiveness of the use of the common lacewing (Chrysopa carnea Steph.) in the control of sucking pests and the cotton moth in cotton. Izvestiya Akademii Nauk Azerbaidzhanskoi SSR . Biologicheskikh Nauk (2) : 92 - 96.

12. Hanafy, A. R. I. 2004 . Studies on the most important cucumber pests in the open field and suitable control programs. Ph.D Thesis Fac. of Agric. Moshtohor, Benha branch, Zagazig Univ. 219- 228. 
178 EFFICIENCY OF SECOND INSTAR LARVAE OF CHRYSOPERLA CARNEA TO SUPPRESS SOME PIERCING SUCKING INSECTS INFESTING CANTALOUPE UNDER SEMI- FIELD CONDITIONS

13. Sayed, A. N., Muhammad Ashfaq and Sherbaz Khan. 2000. Comparison of development and predation of Chrysoperla carnea (Neuroptera : Chrysopidae) on different densities of two hosts, Bemisia tabaci and Amrasca devastans. Pakistan Entomologist. 27 (1): 41- 44.

14. Shuvakhina, E. Ya and Novozhilov. 1987. Biological characteristics of Chinese lacewing. Intro-duktsiya- okklimatizatsiya - selektsiya entomofagov 69 -77.

15 .Turquet, M., J. J.Pommier, M. Piron, E. Lascaux and G. Lorin. 2009. Biological control of aphids with Chrysoperla carnea on strawberry. Acta. Horticulturae. 842 : 641- 644.

16. Ushechekov, A. T. 1989. Chrysopa perla for aphid control. Zashchita Rastenii (Moskva). 11: 20 - 22.

17 . Vighi, M., D. Sandroni, S. Otto, A. Finizio, P. Tremolada and G. Zanini. 1997. Volatilization of terbuthylazine and alachlor from agricultural fields in : Final program and Book of abstracts of $9^{\text {th }}$ Int. Symp.of environmental pollution and its impact on life in the Mediterranean region, 4-9 October, 1997.Ed.by MES, AEP, S. Agnello Disorrentto, Italy, P.97.

18. Zaki, F. N., M. F. Shaarawy, and N. A. Farag. 1999. Release of two predators and two parasitoids to control aphids and whiteflies. Anzeiger fur schadlingskunde. 72 (1) : 19-20. 


\section{كفاعة العمر اليرقى الثانى للمفترس الحشرى أسد المن}

\section{فى القضاء على بعض الحشرات الثاقبة الماصة التى تصيب نباتات الكنتالوب}

\section{تحت ظروف نصف حقلية}

$$
\begin{aligned}
& \text { محد وجدى فريد يونس } 1 \text { ، إبر اهيم فتحى إبر اهيم شكرى } 2 \\
& \text { سامية أحمد جلال متولى 3 ، يمنى نبيل محمد عبدالله } 3 \\
& \text { 1. قسم علم الحبوان - كلية العلوم - جامعة المنوفية- مصر. } \\
& \text { 2. قسم علم الحبوان - كلية العلوم - جامعة الزقازيق - مصر. }
\end{aligned}
$$

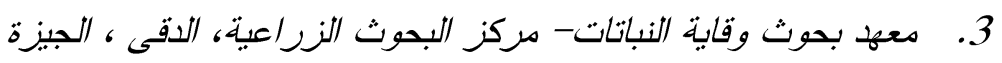

لدراسة كفاءة العمر اليرقى الثانى من المفترس الحشرى أسد المن ، تم إطلاق يرقات المفترس





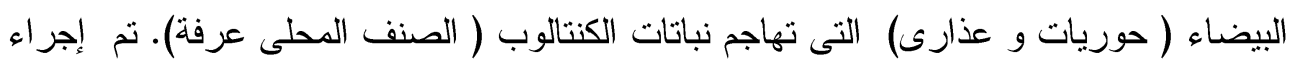

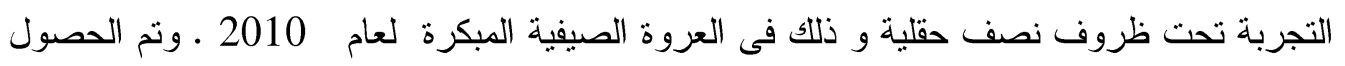

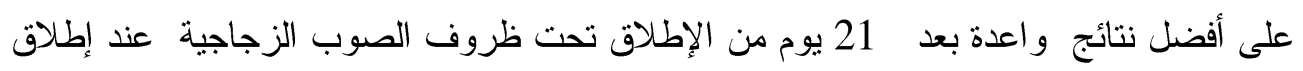
المفترس الحشرى بمعدل 5 يرقات / نبات حيث أدت إلى خفض أعداد المن و الذبابة البيضاء بنسب

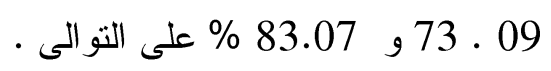

